\title{
Increased effectiveness of firefighting during internal fires with the use of positive pressure attack
}

\author{
Marcin Łapicz ${ }^{1,}$, Radosław Makowski ${ }^{1}$, Jarosław Jędrzejas ${ }^{2}$ \\ ${ }^{1}$ The Main School of Fire Service, Faculty of Fire Safety Engineering, 52/54 Słowackiego St., 01-629 \\ Warsaw, Poland \\ ${ }^{2}$ County Headquarters of the State Fire Service, 2 Objazdowa St., 34-310 Żywiec Poland
}

\begin{abstract}
Internal fire carries a real threat to health and life, not only of the injured people inside but also rescuers. This is due to the impact of toxic gases, as well as the possibility of dynamic and at the same time dangerous fire phenomena. Despite the constant progress of knowledge about internal fires and the phenomena governing them, as well as the development of technologies and tactics to fighting them, it is still difficult to locate a fire. Researches carried out over the last years, aimed at improving the effectiveness and quality of firefighting activities in residential areas, have now created the most effective and safe technique known as positive pressure attack. It is based on carrying out extinguishing activities inside a fire-covered room under the cover of air generated by mechanical-positive pressure ventilation. Appropriate execution of this technique is possible only through systematic practical exercises supported by thorough theoretical knowledge in the field of fire development dynamics. Taking into account the latest achievements of specialized research centers in the world, this paper presents and characterizes the most important components of the positive pressure attack aimed at increasing the safety and effectiveness of firefighting operations.
\end{abstract}

\section{Positive Pressure Attack (PPA)}

Positive pressure attack is a technique of fighting internal fires consisting of the direct use of positive pressure ventilation combined with parallel extinguishing activities [1-4]. This technique is based mainly on the orientation of the gas exchange path in the fire facility between the previously identified openings in order to shorten the time of the location of the fire [5-9]. It is one of the more complex methods that in a correctly carried out way significantly affects the safety of the injured and rescuers while improving the comfort of the activities carried out [10-16]. The correct implementation of the overpressure attack is possible only with the provision of properly trained people, accurate identification of the fire situation, the use of mechanically assisted positive pressure ventilation, as well as the

\footnotetext{
* Corresponding author: mlapicz@sgsp.edu.pl
} 
selection of appropriate fire extinguishing techniques depending on the existing fire situation [17-23]. Therefore, this chapter focuses on the approximation of all the abovementioned issues as much as possible.

\subsection{Tactical ventilation in fire attack}

Tactical ventilation consists of activities based on ventilation or fire isolation in order to gain control over its burning conditions to obtain a tactical advantage during internal RFF operations [24-26]. Tactical ventilation is an indispensable element of a properly conducted overpressure attack, hence the following section describes the criteria and components affecting its success [27-30]. One of the main elements affecting the quality of the conducted overpressure attack is properly carried out tactical ventilation. Effective removal of flammable, hot, and also toxic fire gases from spaces susceptible to their impact is possible first of all while ensuring a properly selected ratio of ventilation openings [31]. Below is a drawing describing the value of the effectiveness of the ventilation performed, depending on the ratio of the area of the ventilation openings (outflow to inlet) [32].

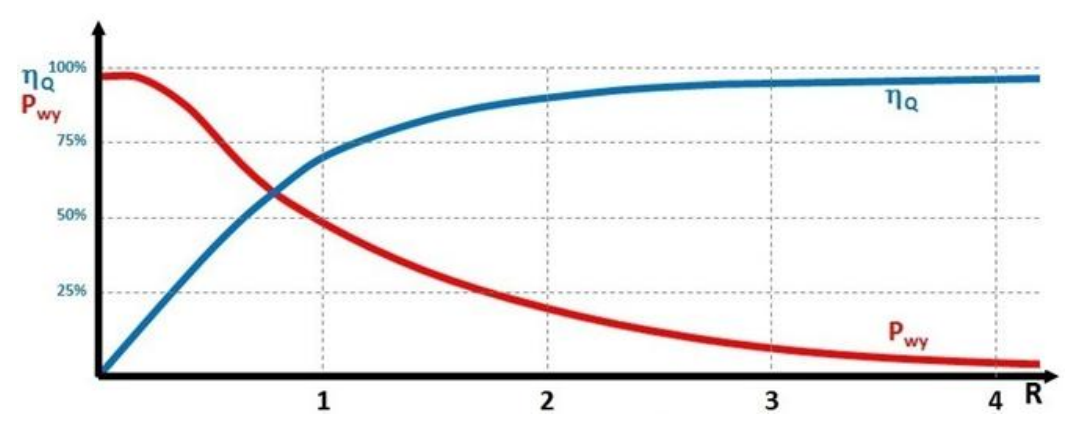

Fig. 1. Effectiveness of ventilation $\left(\eta_{Q}\right)$ carried out depending on the ratio of the area of ventilation openings $\left(\mathbf{P}_{\mathrm{wy}}\right)$.

As can be seen from the graph above, the output and outlet pressures depend on the ratio of the total area of the outlet openings to the surface of the inlet opening. By increasing the outlet area, we increase the outlet expenditure. At the same time, by increasing the surface of the outlets relative to the inlet we reduce the pressure in the outlet or in the outlets [33-37]. This is important because at a certain level of ventilation apertures the pressure in the outlet is so small that the ventilation can be disturbed or even completely prevented by the occurring wind.

\subsection{Procedure of PPA}

If you want to apply the PPA correctly, you should first determine what type of fire you are dealing with. Is it a fire controlled by ventilation or fuel? Ventilation fire controlled by ventilation can be associated with an increased probability of dynamic and dangerous phenomena [38-40]. As a result, we can deal with its rapid intensification causing the possibility of a flashover phenomenon and even a reverse sequence of flames. Venting a fire controlled by fuel does not significantly affect its development dynamics due to the sufficient amount of oxidant in the combustion zone. An unambiguous definition of the stage of a fire is difficult. It should, therefore, be assumed that the fire that we deal with is controlled by ventilation [41-43].

The following is a brief description of the stages contained in the correct implementation of the hypertensive attack: 
a) preparing the team to start an internal attack,

b) determining the place of the occurring fire,

c) determine the location of ventilation openings.

d) preparation of the fan to start ventilation,

e) execution of the outlet opening closest to the place of fire,

f) starting ventilation,

g) fire attack.

Proper implementation of this technique must be based on purposeful, and at the same time thought-out and coordinated action, taking into account the fact that the greatest effectiveness of these activities is obtained in the case of objects with a very complex layout of rooms [44-47].

\section{Test of PPA}

This part presents the individual components of the tests to determine the speed of air flow in the tested part of the trainer, as well as the temperature of fire gases at three different room heights for different fire scenarios [48-51]. It also presents the characteristics of the object, the necessary measuring equipment, as well as the selection of the preferred fan and extinguishing techniques.

\subsection{Main research tool}

In the conducted research, the system shown in the figure below was used, which is part of a simulator for simulating internal fires of the Main School of Fire Service. Dimensions of the presented part of the building imitation are approximately $12 \mathrm{~m}$ (length) $\mathrm{x} 4.6 \mathrm{~m}$ (width) $\mathrm{x} 2.5 \mathrm{~m}$ (height), which gives an area of approximately $55 \mathrm{~m}^{2}$ and a cubage equal to $138 \mathrm{~m}^{3}$, comparable to a medium-sized flat.

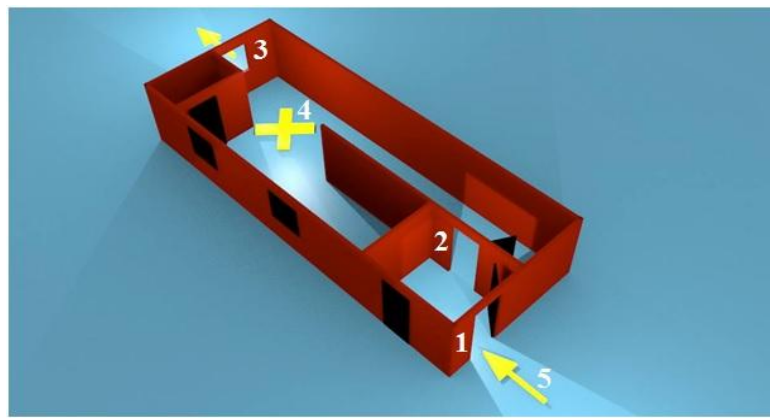

Fig. 2. Visualization of a part of a simulator for simulating internal fires in which the tests were carried out.

The numbers in the figure indicate in sequence:

1. Inlet opening (door: $90 \mathrm{~cm} \times 200 \mathrm{~cm}$ ),

2. Doors (between the first room and the second with dimensions: $90 \mathrm{~cm} \times 200 \mathrm{~cm}$ ),

3. Outlet opening (window) located at a height of $105 \mathrm{~cm}$ from the level of the floor with dimensions from left to right: $55 \mathrm{~cm}$ x $105 \mathrm{~cm}, 110 \mathrm{~cm}$ x $105 \mathrm{~cm}, 220 \mathrm{~cm} \times 105 \mathrm{~cm}$,

4. Place of placing the tray with combustible material (veneered boards), weight approx. $50 \mathrm{~kg}$,

5. Marking the direction of the flowing stream of air produced by the fan. 


\subsection{Results of the survey}

The tests consisted in determining by means of an anemometer the velocity of the flowing air stream produced with the Leader MT 236 EPT fan through the holes in the tested part of the trainer. Three measurements were carried out for each of the distances mixing in the field of work preferred by the manufacturer of this fan, with a value of $2.4 \mathrm{~m}, 2.6 \mathrm{~m}$ and 2.8 $\mathrm{m}$ respectively, from the front door. Due to various types of restrictions in the form of, for example, walls, or porches, the suggested fan setting may not be feasible. Considering the above, the measurements made were aimed at a kind of simulation of the conditions that usually occur during fires of residential buildings

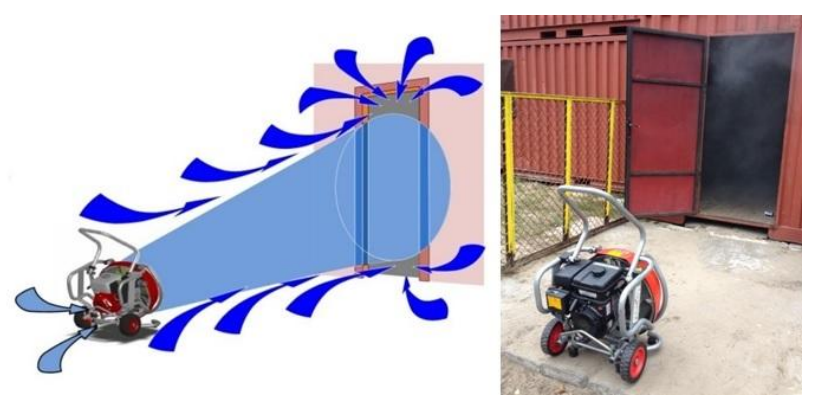

Fig. 3. The principle of operation of a turbo-fan (Venturi effect) and its location during air flow velocity measurements.

The table below presents the results of airflow flow measurements for outlet openings with the following dimensions: $55 \mathrm{~cm} \times 105 \mathrm{~cm}, 110 \mathrm{~cm} \times 105 \mathrm{~cm}, 220 \mathrm{~cm} \times 105 \mathrm{~cm}$ and the fan distance from the inlet of $2.6 \mathrm{~m}$. This value has been selected due to the best performance of the turbo-fan. During the measurements carried out, the atmospheric conditions were omitted due to the lack of their effect on the fan's operation and the impact on the flows obtained in the middle of the simulator.

Table 1. The results of air flow velocity measurements for a $55 \mathrm{~cm} \mathrm{x} 105 \mathrm{~cm}$ outlet.

\begin{tabular}{|c|c|c|c|}
\hline & $\begin{array}{c}\text { Door } \\
\text { (inlet hole) } \\
\mathbf{9 0} \mathbf{~ c m ~} \mathbf{2 0 0} \mathbf{~ c m}\end{array}$ & $\begin{array}{c}\text { Door } \\
\text { (necking) } \\
\mathbf{9 0} \mathbf{~ c m ~} \mathbf{2 0 0} \mathbf{~ c m}\end{array}$ & $\begin{array}{c}\text { Window } \\
\text { (outlet hole) } \\
\mathbf{5 5} \mathbf{~ c m} \mathbf{~} \mathbf{1 0 5} \mathbf{~ c m}\end{array}$ \\
\hline $\mathbf{V}_{\mathbf{1}}[\mathbf{m} / \mathbf{s}]$ & 5,0 & 2,1 & 4,9 \\
\hline $\mathbf{V}_{\mathbf{2}}[\mathbf{m} / \mathbf{s}]$ & 5,4 & 3,3 & 5,3 \\
\hline $\mathbf{V}_{\mathbf{3}}[\mathbf{m} / \mathbf{s}]$ & 6,1 & 3,6 & 4,2 \\
\hline $\mathbf{V}_{\text {average }}[\mathbf{m} / \mathbf{s}]$ & $\mathbf{5 , 5}$ & $\mathbf{3 , 0}$ & $\mathbf{4 , 8}$ \\
\hline
\end{tabular}

Table 2. The results of air flow velocity measurements for a $110 \mathrm{~cm}$ x $105 \mathrm{~cm}$ outlet.

\begin{tabular}{|c|c|c|c|}
\hline & $\begin{array}{c}\text { Door } \\
\text { (inlet hole) } \\
\mathbf{9 0} \mathbf{c m} \mathbf{~ 2 0 0} \mathbf{~ c m}\end{array}$ & $\begin{array}{c}\text { Door } \\
\text { (necking) } \\
\mathbf{9 0} \mathbf{c m} \mathbf{~ 2 0 0} \mathbf{~ c m}\end{array}$ & $\begin{array}{c}\text { Window } \\
\text { (outlet hole) } \\
\mathbf{1 1 0} \mathbf{~ c m} \mathbf{~ 1 0 5} \mathbf{~ c m}\end{array}$ \\
\hline $\mathbf{V}_{\mathbf{1}}[\mathbf{m} / \mathbf{s}]$ & 7,6 & 2,9 & 2,9 \\
\hline $\mathbf{V}_{\mathbf{2}}[\mathbf{m} / \mathbf{s}]$ & 6,5 & 3,9 & 2,5 \\
\hline $\mathbf{V}_{\mathbf{3}}[\mathbf{m} / \mathbf{s}]$ & 8,1 & 4,3 & 3,6 \\
\hline $\mathbf{V}_{\text {average }}[\mathbf{m} / \mathbf{s}]$ & $\mathbf{7 , 4}$ & $\mathbf{3 , 7}$ & $\mathbf{3 , 0}$ \\
\hline
\end{tabular}


Table 3. The results of air flow velocity measurements for a $220 \mathrm{~cm}$ x $105 \mathrm{~cm}$ outlet.

\begin{tabular}{|c|c|c|c|}
\hline & $\begin{array}{c}\text { Door } \\
\text { (inlet hole) } \\
\mathbf{9 0} \mathbf{~ c m ~} \mathbf{2 0 0} \mathbf{~ c m}\end{array}$ & $\begin{array}{c}\text { Door } \\
\text { (necking) } \\
\mathbf{9 0} \mathbf{c m} \mathbf{~ 2 0 0 ~ c m ~}\end{array}$ & $\begin{array}{c}\text { Window } \\
\text { (outlet hole) } \\
\mathbf{2 2 0} \mathbf{~ c m ~} \mathbf{~ 1 0 5 ~ c m ~}\end{array}$ \\
\hline $\mathbf{V}_{\mathbf{1}}[\mathbf{m} / \mathbf{s}]$ & 6,5 & 4,3 & 2,5 \\
\hline $\mathbf{V}_{\mathbf{2}}[\mathbf{m} / \mathbf{s}]$ & 9,1 & 3,8 & 1,2 \\
\hline $\mathbf{V}_{\mathbf{3}}[\mathbf{m} / \mathbf{s}]$ & 6,9 & 4,2 & 2,0 \\
\hline $\mathbf{V}_{\text {average }}[\mathbf{m} / \mathbf{s}]$ & $\mathbf{7 , 6}$ & $\mathbf{4 , 1}$ & $\mathbf{1 , 9}$ \\
\hline
\end{tabular}

On the basis of the conducted tests, it can be noticed that as the outlet opening increases, the flow value at the inlet to the room increases and the outlet decreases. This is due to the possibility of better air suction and the possibility of its outlet after the creation of overpressure in the room. It can also be stated that the amount of air leaving a ventilated room depends mainly on one variable parameter and two constants. Measuring, therefore, one variable parameter, which is the air velocity at the outlet, you can determine the view regarding the efficiency of ventilation, while adjusting, for example, the distance of the fan from the inlet or changing the model.

\section{Conclusions}

This work was aimed at assessing hypertensive attack techniques when extinguishing internal fires in living quarters. The following conclusions were drawn from the conducted research:

a) limiting the air supply to a room covered by fire is an indispensable element affecting the reduction of the dynamics of fire development, as well as its power. Safe and effective fight against internal fires requires appropriate knowledge in the field of fire theory and the ability to adapt techniques to the extinguishing activities carried out,

b) the measure of the efficiency of the fan is not nominal efficiency, only the ability to produce a directed flow, as well as the multiplicity of gas exchange in a ventilated volume. Knowledge of the operational parameters of a given fan is the main factor affecting properly conducted tactical ventilation,

c) location of the fan in a way that ensures the covering of the air cone produced in the inlet hole (in the tested case of the door) is not an indispensable factor for effectively conducted tactical ventilation,

d) appropriately selected sizes of ventilation openings affect the possibility of faster and more efficient removal of combustible fire gases, reducing the risk of dangerous phenomena that can significantly affect the intensification of the fire,

e) as a result of a directed air stream created with the use of an overpressure fan, the likelihood of property damage due to the influence of fire gases on the building furnishings is reduced,

f) the use of tactical ventilation affects the temporary increase in the rate of heat released in the first phase of its application. Nevertheless, one should take into account the fact that soon after, as a result of removing fire gases (in which approximately $2 / 3$ of the heat released in a fire is accumulated), the conditions are significantly improved, increasing the effectiveness and safety of the rescue operations carried out,

g) correctly carried out hypertensive attack ensures quick localization and elimination of fire. Synchronization of particular activities presented in the algorithm regarding hypertensive attack technique requires thorough knowledge of carrying out such activities, as well as the equipment necessary to carry it out, 
h) the use of hypertensive attack extends the survival conditions of people injured in the danger zone by reducing the impact of flammable and also toxic fire gases. It improves the improvement of visibility conditions and is connected with the quick and effective access to the source of the fire, as well as the efficient evacuation,

i) the use of a pressure overload contributes to a faster determination of the place of fire, as well as a reduction in the need for the amount of extinguishing agents. Due to the occurrence of overpressure on the way of directed air flow, the resulting combustion products as well as steam generated as a result of extinguishing on a regular basis are removed outside the fire-covered building,

j) the use of hypertensive attack in the event of a fire taking place in the basement or on the first floor of a given building is based mainly on criteria such as a fire occurring on the ground floor. The necessary condition to be met is the ratio of the size of individual inlet and outlet openings and the direction of the air flow in a way that ensures the shortest possible gas exchange route. Depending on the type of building and its cubature, it is recommended to use more fans in order to ensure greater effectiveness of the activities carried out,

k) the use of overpressure rake is associated with the escape of flames, outside the fire compartment. In this regard, special care should be taken to ensure that flames or hot and flammable fire gases do not cause the fire to spread to other structural elements by providing a fire-fighting station near the outlet opening,

1) the use of tactical ventilation in the event of the probability of occurrence of smoldering, glowing or fading surfaces causes the risk of re-intensification of fire, hence the use of thermal imaging cameras is important in order to avoid a recurrence of smoking,

$\mathrm{m}$ ) an inseparable element in the fight against internal fires is the probability of dangerous fire phenomena. It should be emphasized, therefore, that a thorough understanding and practice of water feeding techniques (cited in this paper) on various trainers reflecting real fire conditions is of key importance,

n) limiting the intensification of the combustion process in the first phase of the actions undertaken in time should be based primarily on the skilful supply of a compact water current from the outside to the ceiling of the room covered by a fire in order to softening the fire,

o) in the case of combat In the case of internal fires in residential rooms, the preferred technique for obtaining the greatest efficiency of cooling fire gases is pulsed feeding of the dispersed water current. In the case of a fire location, it is a scanning technique in combination with a pencil technique. However, it is necessary to know all the techniques of water supply due to the variability of the parameters characterizing the combustion process, p) inadequately conducted tactical ventilation may lead to various types of dangerous fire situations that can significantly affect the health and lives of firefighters, as well as people who are injured.

\section{References}

1. S. Svensson, Fire Ventilation, Karlstad (2000)

2. A. Piechota-Polanczyk, A. Kopacz, D. Kloska, B. Zagrapan, C. Neumayer, A. Grochot-Przeczek, I. Huk, C. Brostjan, J. Dulak and A. Jozkowicz, Oxid Med Cell Longev 2018 (2018)

3. K. Kowalska, D. E. Habrowska-Gorczynska, C. Neumayer, M. Bolliger, C. Domenig, A. W. Piastowska-Ciesielska, I. Huk and A. Piechota-Polanczyk, Acta Biochim Pol 65, 1 (2018)

4. D. Dmochowski, A. Dmochowska, S. Biedugnis, ROS 17 (2015) 
5. M. Tytla, A. Dmochowska and D. Dmochowski, E3S Web of Conferences 44, (2018)

6. A. Zieminska-Stolarska, A. Polanczyk, I. Zbicinski, J. Hydrol. Hydromech. 644, 8 (2015)

7. A. Polanczy, T. Wozniak, M. Strzelecki, W. Szubert, L. stefanczyk, Signal Processing SPA 5 (2016)

8. T. Wesierski, M. Majder-Lopatka, R. Matuszkiewicz, R. Porowski, Przem. Chem. 91, 3 (2012)

9. T. Wesierski, M. Majder-Lopatka, W. Wasik, Przem. Chem. 96, 5 (2017)

10. M. Majder-Lopatka, W. Rogula-Kozlowska, W. Wasik, E3S Web of Conferences 44 (2018)

11. A. Polanczyk, M. Podyma, L. Trebinski, J. Chrzastek, I. Zbicinski, L. Stefanczyk, PLoS One 11 (2016)

12. M. Majder-Lopatka and T. Wesierski, E3S Web of Conferences 46 (2018)

13. M. Majder-Lopatka, T. Wesierski, W. Wasik, BITP 42, 8 (2016)

14. M. Polka, Z. Salamonowicz, M. Wolinski, B. Kukfisz, Procedia Eng. 45 (2012)

15. Z. Salamonowicz, W. Jarosz, BITP 3 (2012)

16. Z. Salamonowicz, M. Kotowski, M. Polka, W. Barnat, Przem. Chem. 93 (2014)

17. Z. Salamonowicz, M. Wolinski, M. Sobolewski, M. Polka, Przem. Chem. 93 (2014)

18. Z. Salamonowicz, M. Kotowski, M. Polka, W. Barnat, Bull. Pol. Ac.: Tech. 63 (2015)

19. A. Polanczyk, A. Piechota-Polanczyk, L. Stefanczyk, PlosOne 12 (2017)

20. A. Polanczyk, M. Klinger, J. Nonobachvili, I. Huk, C. Neumayer, Appl. Sci. 8, 12 (2018)

21. A. Polanczyk, M. Strzelecki, T. Wozniak, W. Szubert, L. Stefanczyk, Found. Comp. Decision Sci. 42, 13 (2017)

22. D. Kloska, A. Kopacz, A. Piechota-Polanczyk, W. Nowak, J. Dulak, A. Jozkowicz and A. Grochot-Przeczek, Vascul. Pharmacol. (2018) [in press]

23. A. Piechota-Polanczyk, A. Goraca, Pharmacol. Rep. 64 (2012)

24. A. Piechota, A. Polanczyk, A. Goraca, Pharmacol. Rep. 63 (2011)

25. A. Piechota, A. Polanczyk, A. Goraca, Pharmacol. Rep. 62 (2010)

26. A. Piechota-Polanczyk, A. Jozkowicz, Curr. Drug Targets. 17 (2016)

27. A. Polanczyk, Z. Salamonowicz, E3S Web of Conferences 44, 8 (2018)

28. K. Garcia, R. Kaufmann, R. Schelble, Positive Pressure Attack for Ventilation \& Firefighting (2006)

29. A. Polanczyk, M. Podgorski, T. Wozniak, L. Stefanczyk, M Strzelecki, Medicina 54, 15 (2018)

30. A. Polanczyk, M. Podgorski, M. Polanczyk, N. Veshkina, I. Zbicinski, L. Stefanczyk, C. Neumayer, Interact. Cardiovasc. Thorac. Surg. (2018)

31. A. Piechota-Polanczyk, M. Wlodarczyk, A. Sobolewska-Wlodarczyk, M. Jonakowski, A. Pilarczyk, K. Stec-Michalska, M. Wisniewska-Jarosinska, J. Fichna, Dig. Dis. Sci. 62 (2017)

32. A. Piechota-Polanczyk, M. Zielinska, D. Piekielny, J. Fichna, Biomed. Pharmacother. 84 (2016)

33. A. Polanczyk, A. Piechota-Polanczyk, C. Domenig, J. Nanobachvili, I. Huk, C. Neumayer, Appl. Sci. 8, 14 (2018) 
34. M. Salaga, U. Lewandowska, D. Sosnowska, P.K. Zakrzewski, A.I. Cygankiewicz, A. Piechota-Polanczyk, M. Sobczak, P. Mosinska, C. Chen, W.M. Krajewska, J. Fichna, Naunyn. Schmiedebergs Arch. Pharmacol. 387 (2014)

35. D. Dmochowski, A. Dmochowska, S. Biedugnis, ROS 17 (2015)

36. A. Polanczyk, M. Podyma, L. Stefanczyk, W. Szubert, I. Zbicinski, J. Biomech. 48 (2015)

37. W. Eilenberg, S. Stojkovic, A. Piechota-Polanczyk, C. Kaun, S. Rauscher, M. Groger, M. Klinger, J. Wojta, C. Neumayer, I. Huk, S. Demyanets, Eur. J. Vasc. Endovasc. Surg. 51 (2016)

38. H. Zatorski, M. Salaga, M. Zielinska, A. Piechota-Polanczyk, K. Owczarek, R. Kordek, U. Lewandowska, C. Chen, J. Fichna, Naunyn. Schmiedebergs Arch. Pharmacol. 388 (2015)

39. P. Grimwood, Euro Firefighter: Global Firefighting Strategy and Tactics, Command and Control and Firefighter Safety (2008)

40. A. Polanczyk, P. Wawrzyniak, I. Zbicinski, Drying Technol. 31, 10 (2013)

41. P. Wawrzyniak, A. Polanczyk, I. Zbicinski, M. Jaskulski, M. Podyma, J. Rabaeva, Drying Technol. 30, 10 (2012)

42. A. Piechota, A. Goraca, J. Physiol. Pharmacol. 62 (2011)

43. W. Jarosz, Z. Salamonowicz, M. Majder-Lopatka, R. Matuszkiewicz, A. Dmochowska, Przem. Chem. 93 (2014)

44. M. Wlodarczyk, A. Sobolewska-Wlodarczyk, A.I. Cygankiewicz, D. Jacenik, A. Piechota-Polanczyk, K. Stec-Michalska, W.M. Krajewska, J. Fichna, M. WisniewskaJarosinska, J. Gastrointestin. Liver Dis. 26 (2017)

45. M. Salaga, L.V. Blomster, A. Piechota-Polanczyk, M. Zielinska, D. Jacenik, A.I. Cygankiewicz, W.M. Krajewska, J.D. Mikkelsen, J. Fichna, J. Pharmacol. Exp. Ther. 356 (2016)

46. A. Piechota-Polanczyk, S. Demyanets, O. Nykonenko, I. Huk, M. Mittlboeck, C.M. Domenig, C. Neumayer, J. Wojta, J. Nanobachvili, M. Klinger, Eur. J. Vasc. Endovasc. Surg. 45 (2013)

47. A. Polanczyk, M. Podyma, L. Stefanczyk, I. Zbicinski, Chem. Eng. Process. 33, 9 (2012)

48. Z. Salamonowicz, R. Makowski, E3S Web of Conferences 44 (2018)

49. S. Kokot-Gora, Wentylatory $i$ wentylacja $w$ straży pożarnej (2016)

50. P. Wawrzyniak, M. Podyma, I. Zbicinski, Z. Bartczak, A. Polanczyk, J. Rabaeva, Drying Technol. 30, 9 (2012)

51. Z. Salamonowicz, M. Majder-Lopatka, BITP 30 (2013) 